Meta

Journal des traducteurs

Translators' Journal

\title{
Subtitling Taboo Language: Using the Cues of Register and Genre to Affect Audience Experience?
}

\section{Roger Baines}

Volume 60, numéro 3, décembre 2015

URI : https://id.erudit.org/iderudit/1036137ar

DOI : https://doi.org/10.7202/1036137ar

Aller au sommaire du numéro

Éditeur(s)

Les Presses de l’Université de Montréal

ISSN

0026-0452 (imprimé)

1492-1421 (numérique)

Découvrir la revue

Citer cet article

Baines, R. (2015). Subtitling Taboo Language: Using the Cues of Register and Genre to Affect Audience Experience? Meta, 60(3), 431-453.

https://doi.org/10.7202/1036137ar
Résumé de l'article

En se basant sur des exemples français-anglais et anglais-français, cet article suggère que dans les films socio-réalistes (représentant des groupes socio-économiques particuliers), le sous-titrage s'appuie sur des repères linguistiques et visuels qui relèvent du genre afin de provoquer des réactions du public face aux expressions considérées comme taboues. Les exemples de sous-titrage sont issus de trois films et l'hypothèse en question est examinée selon trois axes interdépendants : i) la pertinence d'envisager le sous-titrage comme un système en soi ; ii) la possible relation entre un genre de film spécifique (en l'occurrence, le socio-réalisme) et les attentes du public en matière d'usage d'expressions considérées comme taboues ; et iii) les représentations du discours à travers le registre employé et ses effets sur la construction des personnages. Cet article nuance les conclusions d'autres recherches dans ce domaine, selon lesquelles les choix déterminant le transfert de l'oral à l'écrit reposeraient sur des restrictions liées à la politesse ou relèveraient d'un effet d'homogénéisation en matière de construction des personnages (Lambert 1990 ; Mailhac 2000 ; Taylor 2006a, par exemple).
Ce document est protégé par la loi sur le droit d'auteur. L’utilisation des services d’Érudit (y compris la reproduction) est assujettie à sa politique d'utilisation que vous pouvez consulter en ligne.

https://apropos.erudit.org/fr/usagers/politique-dutilisation/ 


\title{
Subtitling Taboo Language: Using the Cues of Register and Genre to Affect Audience Experience?
}

\author{
ROGER BAINES \\ University of East Anglia, Norwich, United Kingdom \\ r.w.baines@uea.ac.uk
}

\section{RÉSUMÉ}

En se basant sur des exemples français-anglais et anglais-français, cet article suggère que dans les films socio-réalistes (représentant des groupes socio-économiques particuliers), le sous-titrage s'appuie sur des repères linguistiques et visuels qui relèvent du genre afin de provoquer des réactions du public face aux expressions considérées comme taboues. Les exemples de sous-titrage sont issus de trois films et l'hypothèse en question est examinée selon trois axes interdépendants: i) la pertinence d'envisager le sous-titrage comme un système en soi; ii) la possible relation entre un genre de film spécifique (en l'occurrence, le socio-réalisme) et les attentes du public en matière d'usage d'expressions considérées comme taboues; et iii) les représentations du discours à travers le registre employé et ses effets sur la construction des personnages. Cet article nuance les conclusions d'autres recherches dans ce domaine, selon lesquelles les choix déterminant le transfert de l'oral à l'écrit reposeraient sur des restrictions liées à la politesse ou relèveraient d'un effet d'homogénéisation en matière de construction des personnages (Lambert 1990; Mailhac 2000; Taylor 2006a, par exemple).

\section{ABSTRACT}

Using French-English/English-French examples, this article puts forward the hypothesis that, in the film genre of social realism (depicting low socio-economic groups), subtitlers use linguistic and visual cues which are embedded in genre to trigger audience reactions to representations of taboo language. Examples of the subtitling of taboo language are drawn from three films and the hypothesis above will be explored along three main interrelated axes: i) the value of treating subtitles as an entire system; ii) the relationship between the specific film genre of social realism (depicting low socio-economic groups) and audience perceptions of taboo language use; and iii) discourse representations through register and its effect on characterisation. Nuances are brought to evidence from existing research which argues that the choices relating to taboo language made in the oral to written mode shift are subject to politeness restrictions in terms of register, and that these choices have a homogenising/levelling effect on characterisation (Lambert 1990; Taylor 2006a; Mailhac 2000 for example).

\section{MOTS-CLÉS/KEYWORDS}

repérage de réaction du public, représentation du discours, réalisme social, sous-titrage, langage tabou

cueing audience reactions, discourse representation, social realism, subtitling, taboo language 


\section{Introduction}

In their influential study of politeness in screen translation, Hatim and Mason (1997: 82) discuss the constraints under which the film subtitler works, commenting that these constraints make it impossible for all meaning values in the source language soundtrack to be relayed and that therefore the subtitler's aim can only be to provide a guide to what is going on in the verbal source text. They continue:

Meaning is then to be retrieved by cinema audiences by a process of matching this target text guide with visual perception of the action on screen, including paralinguistic features, body language etc. Consequently, any phrase by phrase comparison of source text and target text for the purposes of translation criticism would be an idle exercise [...] What is an altogether more legitimate subject of investigation, however, is to ascertain whether there is any consistent pattern in the kinds of values/signals/ items which are perforce omitted in translated dialogue. (Hatim and Mason 1997: 82)

Taboo language is one example of the type of item referred to by Hatim and Mason which is frequently omitted in audiovisual translation. Taboo is subject to restriction or prohibition resulting from social or other conventions, and taboo language is thus language which is also restricted or prohibited. Fawcett (1997: 119), for example, comments on the subtitling of the broader category of slang which often contains taboo language, "[s]lang seems to be quite regularly expunged or weakened in the translation of films," while Díaz Cintas and Remael (2007: 195) note that taboo words, swearwords and interjections "are often toned down in subtitles or even deleted if space is limited [...]." By comparison with the extensive research on other aspects of audiovisual translation, the body of work on taboo language is comparatively modest but it shows that practice can be considerably more varied and nuanced than the general tendency presented by Fawcett and Diaz Cintas and Remael encompassing a range of strategies, including omission and attenuation, but also retention and intensification of taboo language.

This article uses French-English/English-French examples to explore the hypothesis that, in the film genre of social realism (depicting low socio-economic groups), ${ }^{1}$ subtitlers use linguistic and visual cues which are embedded in genre to trigger audience reactions to representations of taboo language. This investigation will be carried out using three main interrelated axes: i) the relationship between the specific film genre of social realism and audience perceptions of taboo language use; ii) discourse representations through register and its effect on characterization; and iii) the value of treating subtitles as an entire system. An overarching theme is that of cues, both linguistic and visual, which subtitlers might be expected to use, to trigger audience reactions ${ }^{2}$ to representations of taboo language within what is a necessarily efficiently composed and highly stylised text. These cues are embedded in genre. The examples are drawn from the following films: Abdellatif Kechiche's L'Esquive (2003); Ken Loach's Raining Stones (1993); and Laurent Cantet's Entre les murs (2008).

\section{Research context}

Although there is clearly scope for much more enquiry into audiovisual translation and taboo language, the topic has regularly attracted the interest of a range of researchers in the past 15 years or so. For example, case study work by the following 
focuses, in part or wholly, on the transfer of taboo language in audiovisual translation: Mailhac (2000); Díaz Cintas (2001); Chen (2004); Scandura (2004); Pujol (2006); Taylor (2006a); Fong (2009); and Greenall (2011). The argument underlined by Hatim and Mason above, that micro-analysis of the subtitling of de-contextualised segments has limitations and that a macro approach to the entire subtitling text as a system is desirable for understanding the impact of choices made by subtitlers is one which has in particular been advanced by Pérez-González (2007) for dubbing and Guillot (2008; 2010; 2012a; 2012b) for subtitling. Their work provides important theoretical background for the topic under investigation here.

Pérez-González (2007: 1), writing about dubbing, notes that neither film theory nor dubbing studies have focused significantly on phenomena beyond those which take place within a single turn-at-talk and have hence "neglected the study of the sequential dimension of film dialogue." Guillot (2012a: 107) comments that "[t]aking the stylized text of subtitles at its face value and in short decontextualised segments is [...] bound to give a limited view of linguistic and cultural representation." This macro approach necessitates an appraisal of the relationship between the entire film dialogue and dubbing/subtitle text (as well as other channels of communication within the film text such as music and sound effects).

Using a systemic functional model of conversation analysis, Pérez-González investigates how interactional naturalness is sequentially constructed in dubbing. Through the identification of mismatches in the depiction of interpersonal dynamics in the Spanish dubbing of Lumet's Twelve Angry Men (1957) which adversely affect the naturalness of translated text, he demonstrates how important it is that dubbing practitioners have a heightened awareness of the sequential configuration of dialogue in order to improve the quality of discourse representations in dubbing. PérezGonzález's work focuses on sequential talk across whole scenes in relation to narrative structures implicitly addressing the approach of assessing factors associated with the entire film in relation to dubbing. Both Pérez-González (2007: 2-12) and Guillot (2012a: 105-108) underline that film dialogue is an artificial representation of naturally occurring speech composed for an overhearing audience and that its content is streamlined further by the requirements of the cinematic process (narrative, camera work, editing etc.; see Freddi and Pavesi 2009). The artificial nature of film dialogue and the constraints that a subtitler has to contend with lead to what is often highly streamlined text in subtitles. It is well documented that subtitling presents specific constraints (time, space, synchronisation) and that these constraints oblige the subtitler to exercise maximum efficiency when creating the 'target-text guide' to promote coherence and readability (see Ivarsson and Carroll 1998; Díaz Cintas and Remael 2007, for example). According to Guillot (2012a: 105), "[t]extually speaking, it would [...] be misguided to expect subtitles to be anything other than highly stylized in relation to source dialogue" since viewers' short-term memory also has to deal with other visual and aural signals, the challenge of dealing with the transfer of features such as register, connotations, culture-specific features and so on in the shift from speech to writing and from one language to another. This challenge is evident in the text of standard subtitles "in their concision and their simple paratactic mode of expression in standalone units" (Guillot 2012a: 105). Non-standard language, including taboo language, just like other oral and interactional features such as dialect or discourse markers, for example, render subtitle text more complex to process within the few seconds they 
appear on screen (between 1 and 6/7 seconds depending on the length of the subtitle). The necessary streamlining of subtitles described above means that it would be reasonable to expect taboo items to be omitted. The subtitler Tveit, commenting on the subtitling of swearwords and the taboo language implied in the expression "fourletter words," observes that omissions do indeed occur to promote readability:

Swearwords are [...] often left out in the target version, but in many cases this seems to be done to enhance readability. After all, a considerable percentage of the SL-words normally have to be left out in order for the viewers to be able to read the subtitles. Since four-letter words do not tend to carry propositional meaning, they are frequently dropped. (Tveit 2004: 114)

Some research illustrates this (Díaz Cintas 2001; Chen 2004; Mattsson 2006; Taylor 2006a, for example). I will argue that the macro factors of genre and register (considered from the perspective of the register that is established for certain characters on their first appearance and its relationship to the register they use in the analysed scenes) can be factors which explain the practice of retaining taboo language in subtitles. However, there is more to the question than a straightforward quantification of the presence or absence of taboo language in subtitles as a consequence of processing constraints. The macro-oriented work of both Pérez-González and Guillot necessarily places considerable focus on questions of audience reception, and the notion of cueing audience experience, developed by Guillot (after Fowler 1991; 2000), is central to this investigation of genre, register and taboo language. The word "cueing" is used in the sense of employing the resource of triggers available in the linguistic and visual text to signal the use of taboo vocabulary or expressions to the audience without the use of subtitles, and not in its more common sense in audiovisual translation which refers to the process of time spotting defining the in and out times of individual subtitles.

Like Pérez-González for dubbing, Guillot (2012a; 2012b) highlights for subtitling the interdependence of linguistic choices and narrative/filmic structure. She draws on Fowler's (1991; 2000) cognitively-driven Theory of Mode which foregrounds multimodality at the level of text itself and takes into account the interaction of text features and readers' perception rather than text features alone (Guillot 2012a: 109) to demonstrate the expressive richness and capacity for representation of subtitles as systems of multimodal textual representation setting their own modes of interpretation. She argues that subtitles have the potential for richer and more complex representation than they are generally given credit for. Fowler's Theory of Mode explains the ways in which advertising texts operate multimodally to produce the illusion of speech by identifying cues which: "trigger particular types of experience and reactions: it only takes a few cues of orality in a written text, for example, for the text to be experienced and responded to as speech. Texts are not characterised as categories of text or structure, in other words, but as categories of experience" (Guillot, 2012b: 483). For Guillot (2012b), the use of cues to trigger audience experience is one way that the constraints of the heightened stylization of film dialogue and subtitles can be negotiated. She makes it clear that the cues she identifies function in conjunction with a range of other features present in the film text as a whole; and, importantly, that they do so (after Fowler 1991; 2000) in a non-random way, that they are, as described above, part of a system: 
Shifting away from the relationship between source dialogues and their subtitles [...] and focusing instead on the representations that subtitles may convey to viewers about other languages and cultures [...] makes room for subtitles to be construed as producing their own systems of multimodal textual representation and modes of interpretation. (Guillot 2012b: 480)

Guillot applies this approach to particular features of, and questions about, subtitling and representation. She does this via an extended analysis of T/V shifts in exchanges between two characters in a French thriller demonstrating in the process how both the characterisation and narrative functions are achieved through the different resources available to the subtitler, which include: register, linguistic form and punctuation cues, but also, significantly, features of subtitling: the terseness of the lines resulting from message reduction and formal simplicity, for example; or omissions and the toning down of non-standard language, which heighten contrasts where items that could be omitted are not or where non-standard language does occur. These features all play an integral part in the interplay and in meaning generation (Guillot 2012a: 113-114).

A similar argument can be extended to the macro-context of genre which, in tandem with the expectations of register set up by the speech and behaviour of specific characters on their first appearance, can work as a trigger which I suggest can lead to taboo language cueing audience reactions in the examples analysed in this article. Genre is part of the overarching system in which the film and its subtitles are operating and sets up expectations in terms of register.

Raising the question of the importance of genre of fiction film in audiovisual translation studies is not wholly new. In his 2004 piece arguing for the need for audiovisual translation research to develop an interdisciplinary approach between film studies and translation studies, Chaume comments on the emergence of work that combines translation theory and discourse analysis to assess genres and text types. However, the studies carried out so far (Agost 1997 and Franco 2001) are restricted to types of audiovisual product such as documentary, fiction film, children's TV programme and do not address different film fiction genres (Chaume, 2004: 13). In contrast, Delabastita's (1990) examination of the status of source and target cultures in relation to one another within the global audiovisual arena includes, in a long list of criteria, the importance for subtitling scholars of considering both the genre of the film and the existence of a comparable genre in the target culture. More recently, Ramière (2006: 160) lists film genre as one of the factors to be assessed in her work on the importance of context in devising strategies for dealing with the translation of culture-specific items. From the perspective of predictability, Taylor (2006b) has written in more detail on film genre and translation suggesting that there is a possibility that translation memory tools could prove useful. He comments in a general discussion on genre that "the expression 'film genre' brings to mind such 'text types' as western, spy story, comedy, etc. but films too have their sub-genres and genrelets" (Taylor 2006b: 4). He argues that it is within the "genrelets," types of interaction within sub-genres such as "emergency telephone calls, third form geography lessons or American football pep talks," that forms of language can be usefully predicted. This is of limited use for the translation of taboo language which does not lend itself to a formulaic predictability of stretches of language. However, the contribution of genre to signalling to the audience that taboo language is likely to be present in 
dialogue is significant. Remael (2004: 105), although she has not analysed it herself, has identified the importance of a greater focus on genre in her argument for training subtitlers to have a better insight into understanding the narrative function of film dialogue. That a film's dialogue derives from genre is examined closely by Kozloff in Overhearing Film Dialogue (2000). She identifies dialogue conventions in four film genres - Westerns, screwball comedies, gangster films, and melodramas - concluding that "most genre description is [...] a distillation and analysis of information about narrative, themes, and character gleaned from the dialogue" (Kozloff 2000: 267). This identification of dialogue conventions within genres is useful because it reinforces the idea that audience will have expectations of dialogue which derive from the film genre. Pérez-González, in investigating dubbed conversation, concurs when he suggests that the "prefabricated orality" of film dialogue derives, in part, from generic stability. He argues that conversational naturalness in film dialogue is achieved through a combination of prefabricated orality and "interactional haphazardness" which is allowed for by register (Pérez-González: 2007: 18). A prominent feature of the prefabricated orality of the genre examined in this article, social realism, is the presence of a distinct register conveyed via the use of taboo language in the dialogue.

\section{Register and characterisation}

Systemic functional linguistics regards texts as "(inter)actions that occur in a cultural and situational context by modelling them as cultural types of unfolding social action - genre - which have features appropriate to their current social situation - register" (Hofinger and Ventola 2004: 194). Register in systemic functional linguistic terms is configured by field of discourse (nature of social interaction), tenor of discourse (social role relationship) and mode of discourse (the channel of communication), see also Hatim and Mason $(1990 ; 1997)$ for applications of systemic functional linguistics to translation. The combination of genre and register will be considered from a holistic perspective in my subtitled examples. An important element in the analysis is the transfer from the spoken to the written mode in relation to characterisation. One frequently identified consequence of the representation of spoken discourse in audiovisual translation is linguistic and cultural homogenisation, often termed levelling. Linguistically, levelling is the elimination of elements of speech which mark register, such as non-standard features of speech, dialect or discourse markers. Levelling dilutes these features in the representation of the discourse, in particular in the shift from a spoken to a written mode in subtitles, and some audiovisual translation researchers argue that this has a detrimental effect on characterisation (see, for example, Lambert 1990; Taylor 2006a; Mailhac 2000). Mailhac, for instance, analyses the subtitling and dubbing of Balasko's Gazon maudit (1995), a comedy about attitudes to homosexuality which involves multiple shifts between registers to signal complex relationships. He reports that the toned-down English subtitles lead to characters being perceived as either less formal or more refined than they actually are. Vandershchelden (2001: 365), in her article on how different classes are subtitled in Chatiliez's La Vie est un long fleuve tranquille (1987), indicates a similar loss of differentiation between characters from different backgrounds because of the use of neutral registers in the subtitles. More specifically on taboo language, Pujol (2006) reports that the dubbing of fuck into Catalan for Rodriguez's 1996 film From Dusk 
till Dawn is inadequate as far as characterisation is concerned because fuck is frequently either not translated, or translated very mildly. Whether the cueing of audience reactions through taboo language in the context under discussion can be argued to have an effect on levelling will be an important question.

\section{Functions of taboo language}

Research into subtitling taboo language reports on and exemplifies strategies of complete omission (Díaz Cintas 2001; Chen 2004; Mattsson 2006; Taylor 2006a) and of attenuation/dilution of taboo language (see Scandura 2004; Taylor 2006a; Mailhac 2000; Díaz Cintas 2001). Both strategies are usually described in subtitling as a consequence of the intersemiotic shift from an oral to a written code because politeness norms are more restrictive for the written word than for speech (see Gambier 2002: 213; Goris 1993; Lambert 1990). However, while it is useful to consider the range of findings relating to the strategies for subtitling taboo language, the distinction between omission and attenuation in particular can be seen as academic if one assesses the function and impact of taboo language use. Once taboo language is attenuated in subtitles, its function is arguably lost, unless the force of the taboo language in the source text film dialogue is recognised by the subtitle audience, in which case it acts as a cue for an audience reaction to taboo language. Indeed, Greenall argues in her analysis of the Norwegian subtitling of swearwords in the 1991 Parker film The Commitments, in which around half of the swearwords are omitted, that one explanation for the high proportion of omitted swearwords for an English language film could be the subtitler's expectation that "a viewer with some knowledge of English ought to be able to recover the swearing directly from the auditory channel" (Greenall 2011: 46).

A potentially more rewarding approach than categorising types of omission is one which assesses the function of taboo language. The most striking functions of taboo language will be those that are particularly evident in the dialogue and will require subtitling, and provide a strong contrast with the register a character has established in preceding dialogue. For example, Renton, the protagonist and narrator in Boyle's Edinburgh-based film about heroin addiction, Trainspotting (1996), is established as one who uses a great deal of non-standard language, both dialect and slang including taboo language (his first lines are Choose life. Choose a job. Choose a career. Choose a family. Choose a big fucking television). Towards the end of the film, he moves to London to try and live life heroin-free and takes up a job as an estate agent. Within this context his register becomes much more standard but shifts again when his friend Begbie turns up in London wanted for armed robbery (How the fuck can it be armed robbery with a fucking replica?!). Thus, the use of non-standard language, including taboo, has a function which relates to characterisation but also a function of signalling the field and tenor of discourse in particular contexts. Shifts in usage of non-standard language in film dialogue such as those described above are expected due to the contexts in which they occur, non-standard language is what Renton uses and so when he reverts to it when working as an estate agent, it may be out of keeping with the context but it is in line with the audience expectations set up for the character from the start of the film. On the other hand, usage of non-standard language, including taboo, can be unexpected when it is neither set up by context 
nor by the established register of a character. Both types require careful consideration by the subtitler but expected shifts can be accounted for through the practice of cueing (partially subtitling taboo language so that all examples do not need subtitling) without adversely affecting plot or characterisation in a way that unexpected, out of character/context, shifts cannot. A strategy of cueing is understood to be the use of linguistic and visual cues which are embedded in genre to trigger audience reactions to taboo language, instead of subtitles, or as a reduction in the number of taboo words or expressions between dialogue and subtitle. Following Mason (2000), after Bell (1984), the audience are "overhearers" in that they are known, unratified participants who are not addressed (Mason 2000: 4).

Another way of assessing the functions of taboo language is to look at what Jay (2009), writing about taboo language from a neuro-psycho-social perspective, describes as "emotion information." He explains that taboo language is used because it can communicate emotions more readily than non-taboo words, allowing speakers to achieve a variety of personal and social goals. According to him, data on naturally occurring swearing shows that two-thirds of the incidence of swearing in his own US-based studies (Jay 1992; 2000) derive from anger and frustration (Jay 2009: 155). This provides what are likely to be the main categories of the emotional functions of taboo language use in the data. ${ }^{3}$

The following questions emerge from the literature review above:

- does the combination of perceived expectations of discourse representation conveyed through taboo language set up by the particular genre of social realism and by the registers of particular characters, promote the strategy of cueing? And is this strategy then an example of a systemic relationship between film dialogue and images, and the subtitles?

- when particular genres and the register of specific characters set up expectations of taboo language use in this way, does this override the perceived politeness restrictions in the transfer of taboo language from the spoken to the written mode?

- does cueing in the particular genre under consideration provide some refinement of existing findings regarding homogenisation/levelling through the omission of taboo language in subtitles?

\section{Methodology}

The analysis is used to explore the overall hypothesis that in the film genre of social realism (in French and British cinema) subtitlers use linguistic and visual cues which are embedded in genre to trigger audience reactions to taboo language. It is based on a small sample of three social realist films: Abdellatif Kechiche's L'Esquive (2003); Ken Loach's Raining Stones (1993); and Laurent Cantet's Entre les murs (2008). Each film provides examples of cueing which I speculate are dictated by different circumstances. Studying commercially available subtitled films is somewhat restricted by what is marketed in the relevant languages. Film certification is one obvious way of identifying film dialogue that may contain taboo language but this does not provide a sufficiently refined categorisation for my purposes. A more specific way of narrowing the search for examples of taboo language use is by using the hypothesis that taboo language occurs most frequently in contexts of conflict or physical violence and that it is more often produced by characters whose sociolect can be characterised 
as one in which non-standard language is prominent. Greenall comments that breaches of what she calls "the swearing constraint" carry "a generalised social implicature of the type: I belong to such-and-such a group of people or such-and-such a subculture, possibly with additional nuances descriptive of the attitudes and values of the given group" (Greenall 2011: 47) and it is the audience expectations that such social implicature establishes that is key to a cueing strategy. While stylised film dialogue is clearly not naturally occurring language, sociolinguistic research shows that the phenomenon of covert prestige has an effect on the increased frequency of usage of non-standard/low-status linguistic forms such as swearing in lower socioeconomic groups (see, for example, Hughes 1992; Chambers and Trudgill 1998). Locating films in specific genres can be problematic, not least because a considerable hybridity of genre is frequently apparent. The films selected for analysis are relatively uncomplicated examples of the genre in which I am positioning them: social realist drama. Hallam and Marshment (2000: 84) describe the social realist genre as represented by "films that aim to show the effects of environmental factors on the development of character through depictions that emphasise the relationship between location and identity." This definition can be applied to the films used as examples with the qualification that they depict groups whose environment reflects a low socioeconomic background because this increases the frequency of low-status linguistic forms. Around 20 social realist films in total, English films subtitled in French and French films subtitled in English, were viewed looking for instances of taboo language use. However, while there were indeed such instances in most of the films viewed, it was rarely sustained in stretches sufficiently long to enable analysis of cueing. Whether this means that cueing is less evident when taboo language use is not sustained in film dialogue is an important point and will be further pursued. As the analysis developed and expected taboo language use and unexpected taboo language use were identified (in terms of context and general register established for the character using the taboo language), as far as possible, films containing examples of both types of use, as well as sustained stretches of taboo language, were identified. This inevitably limited the size of the data set.

The prominence of arguments or aggression (involving characters from low socio-economic backgrounds who routinely use non-standard taboo language) is another shared characteristic of the three films selected and served as an additional guiding factor in the selection of the films. L'Esquive depicts a group of teenagers in a disenfranchised French banlieue (council estate/housing project). It focuses on the rise and fall of a relationship between Lydia and Krimo who are rehearsing for the main roles in a school production of Marivaux's Le Jeu de l'amour et du hasard. Raining Stones depicts an unemployed father's conflict with violent moneylenders as he struggles to survive crippling debt in 1990s Manchester. The characters focussed on for analysis are the main protagonist, Bob, and the bouncers in the nightclub he finds work in for a few hours. Entre les murs depicts the relationship between a teacher and his class in a school in a deprived inner-city Parisian area over a school year. The characters who appear in the analysed scenes are the French teacher Marin and the students, notably Esméralda.

Using Halliday's discourse register model (1985) and applying it from an overall macro perspective, the field of discourse (nature of social action) for the examples can be generalised to a depiction of a narrative which encompasses the following 
subject matter: teenage conflict and romance in a French banlieue (L'Esquive); poverty and loan sharks in 1990s Manchester (Raining Stones); and the battles involved in educating disadvantaged children in a Parisian school (Entre les murs). The tenor of discourse (social role relationship) can be described as one in which the context/ speech community is one where the low socio-economic background of a majority of the characters promotes the use of non-standard language in the exchanges. Field and tenor of discourse contribute to the genre of the film. There is in all three of the films a thematic undercurrent of violence and/or conflict which when it comes to the surface privileges the use of taboo language to varying degrees. The mode of discourse (channel) in the films is spoken and the significance of the mode shift in subtitles has already been highlighted. The holistic approach to register used here requires the register established on their first appearance in the film by the characters who are the subject of analysis to be established in terms of field and tenor. The register used on first appearance provides some measure of the audience's expectations of discourse and enables the subtitling of the two types of taboo language to which I am drawing attention - expected and unexpected - to be analysed in terms of context and function. The identification of the practice of cueing requires an understanding of those audience expectations. Each of the four examples which follow present different characteristics and demonstrate a range of ways in which the subtitlers have dealt with taboo language. The analysis will provide a description of the register employed on their first appearance in the film by the characters who feature in the examples, and then the field and tenor of discourse in the extracts analysed will be identified, as will the emotional function (after Jay) of the dialogue. Then the analysis of the omission or retention of taboo language in the subtitles will inform the discussion of cueing strategy, the effect of a cueing strategy on characterisation and the significance of politeness restrictions in any omissions.

\section{Analysis of examples}

\subsection{Example 1: L'Esquive}

Both Fathi and Frida are established on their first appearance as characters who use slang and taboo language with their peers. Fathi's first appearance is in an animated discussion with other members of his gang about an attack on one of their number, which opens the film. Much of the dialogue in this scene is not subtitled at all because it is so rapidly exchanged with a great deal of overlapping and of non-standard language, space and time processing constraints make subtitling impossible. The use of taboo language can be detected in Fathi's speech, among that of other characters in the film dialogue of this scene: fils de pute/motherfucker, for example. Frida first appears at a rehearsal in the amphitheatre to which Lydia has arrived late bringing Krimo unannounced. Frida objects and uses many non-standard forms and taboo language in this scene: j'en ai rien à branler des costumes/costumes don't mean shit, les habits, franchement, on n'en a rien à foutre/it's not the threads you wear, c'est toi qui fait toutes les emmerdes là!/you're crazy, the trouble's you!. Both Fathi and Frida routinely use non-standard forms and taboo language throughout the film. Enough of the dialogue in Fathi's opening scene is intelligible to establish character and the depiction of a context/speech community, as it also does in Frida's first scene. The 
context/speech community depicted is a disadvantaged, low socio-economic, marginalised one, the speech of which is characterised by the use of non-standard forms and taboo language. The scene analysed brings Fathi and Frida together.

Scene: empty outdoor amphitheatre area. Fathi has approached Frida who is sitting on the steps. He suddenly snatches her mobile phone on which she was speaking. They have been arguing for a minute or so when the conversation about Frida's friend (Lydia)'s treatment of Fathi's friend (Krimo) becomes physically aggressive.

(1) Fathi: Oui, toi et tes copines là, moi, je vais toutes vous niquer votre race si vous continuez comme ça OK? If you and your friends carry on, I'll fuckin' waste you

(2) Frida: Mais j'en ai rien à foutre, je suis pas dedans, putain! It's not my fuckin' problem, okay?

(3) Fathi: T'es folle ou quoi? T'es folle, j’tai dit arrête de crier, t'es tout le temps en train de crier. You're crazy. Quit yellin'

[Frida tries to reach the phone]

(4) Fathi: À quoi tu joues, là? À quoi tu joues? What's your game?

(5) Frida: Quoi? À quoi, je joue? My game?

[Fathi crushes Frida's hand]

(6) Frida: Lâche ma main! Ah! Lâche ma main! Putain, lâche ma main! Let go of my hand. Fuckin' let go of my hand!

(7) Fathi: Là, tu vas aller faire quoi là, tu vas aller parler à ta copine, sa mère la pute, cette pute, là, tu vas aller la voir. Know what you're gonna do? Go see that filthy ho.

(8) Tu lui dis, hein? Si elle continue je vais la défoncer. Krimo, c'est pas un bâtard. And tell her I'll waste her unless she backs off my homey.

(9) Frida: Mais j'en ai rien à foutre, tu me lâches et puis c'est tout, putain! I don't give a shit. Let go!

(10) Fathi: Tu vas te calmer ou je vais t'en mettre une. Chill or I'll clock you.

(11) Parce-que moi aussi je commence à péter un câble. I'm blowin' a fuse too.

(12) Elle est en train de le faire tourner en rond, elle le fait kiffer pour rien. She's there, teasin' him...

(13) Tu sais, l'autre pute, tu sais de qui je parle? You know the ho I mean?

(14) Frida: Oui, j’ai compris, ah! Je vais aller la voir. J'ai compris, putain! I know! I'll go see her, okay? 
Both the field of discourse - physically aggravated argument about behaviour of mutual acquaintance - and the tenor of discourse - male youth gang leader dominating younger woman - set up the discourse properties of the exchange, which include taboo language use. The taboo language in the film dialogue has the function of reinforcing the characterization of Fathi and Frida while also signaling the aggressive and conflictual nature of the exchange. It reinforces aggression, threat, accusation and defence. Jay's emotional functions applied here cover the expression of anger/ outrage and frustration. The use of taboo language arguably adheres to the language use set for the characters by what the audience knows of their language use already and of the context/speech community they inhabit. The situation of conflict in this scene enhances the likelihood of taboo language use in the dialogue and the consequent expectation of taboo language in the subtitles. Aside from the conversion of the taboo word bâtard to the low register but non-taboo word homey (line 8), there are only two instances where the taboo language is not retained (lines 9 and 14). While these omissions could be explained as a consequence of the pressure on processing time, it is notable that the other subtitles in the extract are compressed versions of the film dialogue but have retained taboo language. Thus I am arguing that the omissions are evidence of a cueing strategy. The expectations set up by the situation of conflict, the rapidity of the verbal exchange, the genre and the established register of the characters means that transferring all the taboo language to the subtitles is unnecessary. In addition, given the number of taboo words which appear in the subtitles in the scene, it is certain that the omitted taboo words are not omitted because they are taboo, nor can it be argued that the omissions affect perceptions of character.

\subsection{Example 2: Raining Stones}

The main protagonist Bob's speech is generally non-standard, marked by use of dialect as well as slang and taboo language but is more standard in a range of situations such as in some scenes with his wife, in front of his daughter and in scenes with his Catholic priest. Bob appears at the beginning of the film with his friend Tommy rustling a sheep which they aim to kill so they can sell the meat. Their conversation in this scene is punctuated by taboo language, for example fucking get one, some bloody job this, I've got the bastard. This initial presentation sets up use of taboo language as a feature of these characters' speech but also, as the film develops and taboo language is sustained in much of the dialogue, as a feature of the low socioeconomic context/speech community in which they are depicted. Father Barry's speech, in contrast, is consistently standard and does not use taboo language. For example, his first words in the film are in church: Now, you see, the church, well we call it the mother church, has decided that when a child reaches the age of seven, the age of reason, it's time for the parents to prepare them for their first holy communion. The first scene I will focus on from this film takes place in the nightclub where Bob has found a few nights' work. It has been preceded by a scene with his fellow bouncers when he gets the job, a scene which is again characterised by the use of nonstandard and taboo language as the other bouncers mock Bob's appearance (didn't know we were advertising for a fucking pot collector); as above, the use of taboo language contributes to the establishment of character but also provides evidence of a 
shared context/speech community. Thus the majority of the characters the audience has already encountered in the scene below have been established as characters who use taboo language.

Scene: nightclub. Bob has spotted some drug dealing between his friend Tommy's daughter Tracey and a man at the top of a flight of stairs. He accuses Tracey of dealing but when her pusher arrives, he attacks him and, as they fight, they pull each other down the stairs. They are then aggressively separated and held back by the rest of the team of bouncers.

[Pusher approaches the arguing Bob and Tracey]

(1) Pusher: What's going on?

Qu'est-ce qu'il y a?

(2) Bob [to Tracey]: Is this the pusher you're pushing for?

C'est pour ce con que tu deales?

(3) Pusher: What?

[untranslated]

(4) Bob [grabbing the pusher]:

Listen mate

[untranslated]

(5) Pusher [resisting and grabbing Bob]:

You fucking get off!

Attends, salaud.

(6) Bob: Get hold of me Tracey!

[untranslated]

(7)

Fucking get down here you bastard!

Je vais te tuer bordel!

[They fall down the stairs fighting as they go, the following dialogue overlaps heavily and none of it is subtitled, the following is what is intelligible]

(8) Bob: I'm going to kill yer

(9) Pusher: You fucking twat!

(10) Bob: You cunt!

You bastard!

(12) Pusher: $\quad$ Fucking twat!

(13) Bob: $\quad$ Fucking pissing twat!

(14) Pusher: Cunt. Get your fucking hands off me!

(15) Bob: I'll get you you cunt

(16) Pusher: Get off me!

[Other bouncers arrive]

(17) Pusher: He’s a fucking nutter!

(18) Bob: You twat!

(19) Pusher: $\quad$ You fucking lunatic! I'll fucking have yer 
[Unintelligible threats and insults]

(20) Nightclub bouncer 1 [picking Bob up]:

What's the fucking score then eh?!

Qu'est-ce qu'il y a?!

(21) Bob:

He's a fucking drug pusher!

C'est un dealer!

(22) Nightclub bouncer 1:

Anyone seen any fucking drugs?!

Qui a vu de la came?!

(23) Nightclub bouncer 2 [restraining and searching the other man]:

I've seen fuck all! Fuck him off!

Que dalle! Jette-le!

(Raining Stones 19935)

The field of discourse - dispute over suspected drug dealing in a nightclub - and the tenor of discourse - inexperienced bouncer accusing customer followed by reprimand and sacking by main bouncer - establish taboo language use as discourse properties of the exchange. The taboo language in the film dialogue contributes to characterisation and signals the aggressive and conflictual nature of the exchange. Jay's emotional functions of taboo language applied here cover anger and frustration, as expected, while taboo language is used to reinforce aggression and accusation. The use of taboo language adheres to the language use set up for the characters, an expectation that derives from what the audience knows of them already and the context/ speech community they inhabit. On the face of it, these functions and expectations are transferred in the subtitles where technically possible through matched use of taboo language in lines 2 and 4 (and in the initial exchange between Bob and Tracey) and by an additional taboo word in the subtitles (con) in line 2. However, neither in the sequence when the two men are tumbling down the stairs, nor in the following sequence where the other bouncers assess the situation, is it completely clear that it is solely the technical consideration of lack of time for the audience to process taboo language which leads to the omissions in the majority of lines. Although the technical constraint of time clearly does impede the subtitling of the rapid exchange of insults as the characters fall down the stairs (17 seconds for more than 8 utterances), arguably the expectations of taboo language use by these characters in this situation are nonetheless fulfilled in the taboo language that is subtitled in lines 4 and 6 at the start of the scene. This is thus, for me, a clear example of cueing: the language use has been established by genre and preceding use of taboo language by the characters in the scene, and by use of taboo language at the start of this scene. Consequently, there is no need to transfer the remaining taboo language, the point has been made. It is also likely that a French speaking audience will have access to the common English taboo words fuck and fucking repeated in the sequence where there are numerous omissions in the subtitles, in the same way that Greenall argues a Norwegian audience will have access to English swearwords used in The Commitments. It certainly cannot be argued here that the omission of taboo language in the subtitles is either for reasons of politeness restrictions in the transfer from a spoken to a written mode or that the omissions have an adverse effect on the perception of character. There is yet another factor in this example which promotes the practice of 
cueing and that is the non-verbal factor. The aggression and physical violence of the fight as the two men fall down the stairs and the physically aggressive intervention of the other bouncers also render the complete transfer of all the taboo language redundant; the factors which cue expected taboo language listed above are combined with physical violence which further promotes the expectation of taboo language use. Greenall argues that:

It is unreasonable to think that someone who does not understand English at all should be able to infer, on the basis of the setting and atmosphere - be it ever so aggressive at times - that there is more swearing going on than the translator lets on, and hence be able to experience the intended measure of communicative effect and to work out the social implicature. (Greenall 2011: 58)

In my view, in this particular example, the setting and atmosphere plus the visual information of the fight on the stairs, are sufficient for someone who does not speak English at all to infer that there is more taboo language being used than is communicated by the subtitler. However, this example of sustained taboo language use is perhaps an uncommon one and, as mentioned earlier, evidence of cueing is likely to be more observable where longer stretches of dialogue contain taboo language.

\subsection{Example 3: Raining Stones}

The second example from Raining Stones occurs towards the end of the film. Bob has just caused the accidental death of the loan shark, Tansey, and takes refuge with the Catholic priest, Father Barry, at his church. The priest has hitherto, as one would expect, used a formal register with no evidence of non-standard or taboo language.

(1) Father Barry: What are you going to do about it, Bob?

Que vas-tu faire Bob?

(2) Bob: I'm going to the police. What else can I do? Aller à la police, quoi d'autre?

(4) Bob: I want you to do that, Father, please.

Je veux que ce soit vous, mon père

(5) Bob: I want you to do it, because I can't

Moi, je ne peux pas

(6) Father Barry: Why should you?

Pourquoi le faire?

(7) Bob: What?

[untranslated]

(8) Father Barry: Tell Anne.

Le dire à Anne

(9) Bob: Tansey's dead

Tansey est mort

(10) Father Barry: Fuck Tansey!

Rien à branler de Tansey! 
(11) Father Barry: May God have mercy on his soul. You didn't kill him Que Dieu ait pitié de son âme. Tu ne l'as pas tué

(Raining Stones 1993; see note 5)

Here, in contrast to the first example from Raining Stones, the field of discourse - exchange about rights and wrongs of reporting a particular crime to the police - and the tenor of discourse - catholic priest emphatically stating solidarity with his impoverished church member - do not establish taboo language use as one of the discourse properties of the exchange. This is an example of a dramatic shift in register which serves plot and the characterisation of Father Barry whose defence of the disadvantaged against the violent moneylenders is strongly reinforced by his emphatic use of the word fuck. Father Barry's language use is consistently standard throughout the film and so there is no preceding taboo language which could cue the experience of taboo language for the subtitle audience and enable omission of taboo language in the subtitle. In addition, the anger function and the force of the utterance would be completely lost in a way that the force of the utterances are clearly not in the bouncers scene analysed above. A similar set of circumstances can be observed for the example taken from Entre les murs.

\subsection{Example 4: Entre les murs}

An example of sustained use of taboo language with minimal omissions and an example of sustained use of taboo language with a high proportion of omissions have been analysed, as has an example of unexpected use of taboo language. The final example is different again because, while it also provides an illustration of a similar breach of expectations of the use of taboo language as in example three, the ensuing dialogue focuses on the use of one particular taboo word. The French teacher of a class of 14-15-year olds, Marin, is first presented in a staff meeting, in a formal setting where his language use is standard and sophisticated (for example, the verb in je viens d'entamer ma quatrième année (I have just started my fourth year). While he does use some non-standard words in informal conversations with colleagues occasionally in the film and as examples when correcting his students' use of French, his speech with his colleagues and with his class is consistently standard. With his class this is in particular because of the educational context but also because he is a French teacher and it is standard, sophisticated French that he is demonstrating to the class in his speech. The students in general and those who figure most in the scene below, in contrast, have difficulty avoiding non-standard speech. The students mostly come from disadvantaged, low socio-economic backgrounds as can be seen in the discussions they have about their home life in class and in the depiction of the parents at the parents' evening. For example, Esméralda's first appearance sees her comment on a joke made about Marin's name (vous vous êtes fait péter là monsieur/He smashed you sir). A major event in the narrative turns on the use of the taboo term in the following scene.

Scene: Marin in front of his class defending himself against an accusation from the class representatives on the recent staff-student meeting at which students' progress is discussed (conseil de classe). The accusation is that he criticized Souleymane, a student whose results have been poor. Marin in turn, criticizes the class represen- 
tatives' behaviour at the meeting. Field of discourse: angry discussion about staff and student behavior. Tenor of discourse: authority figure criticizing students' behaviour.

(1) Marin: Moi je suis désolé mais rire comme ça en plein conseil de classe c'est ce que j'appelle une attitude de pétasse You were giggling like a couple of tarts

[Gasps of shock at the use of the word pétasse from the class]

(2) Esméralda: Mais vous pétez un câble ou quoi?! Have you blown a fuse?!

(3) Louise: Mais monsieur, ça se fait pas de traiter ses élèves You can't call your pupils

(4) Marin: $\quad$ On dit pas traiter, on dit insulter The word is "insult"

(5) Esméralda: Mais vous pétez un câble de nous insulter de pétasses ou quoi? You can't insult us tarts

(6) Marin: Non, non on dit «traiter de» ou «insulter», «je vous ai traité de pétasses» ou «je vous ai insultées» mais pas les deux à la fois No, you either say I called you tarts or I insulted you, not both

(7) Esméralda: Ouais, ouais garde la pêche Yeah right

(8) Marin: $\quad$ Et d'ailleurs... Anyway...

(9) Marin: J'ai insulté personne ici, je n’ai pas dit que vous étiez des pétasses, j’ai dit qu'à un moment donné...

I didn't call you tarts. I said that at one point...

(10) Marin: $\quad$...du conseil de classe, précisément... ...during the meeting...

(11) Marin: $\quad$...vous aviez une attitude de pétasse, hein, vous voyez la différence ou pas? ...your attitude was tarty...

(12) Carl: Arrêtez d'embrouiller les gens. Vous avez dit "pétasses», c'est tout, c'est trop facile

Don't confuse us. You said "tarts"

(13) Marin: Je ne suis pas en train de vous embrouiller, je suis en train de poser une nuance, tu sais ce que c'est une nuance?

I'm explaining the nuance, get it?

(14) Souleymane: Eh! On parle pas comme ça aux filles, monsieur, vous croyez pas You don't talk to girls like that

(The Class 2008 ${ }^{6}$ )

The scene disintegrates into Souleymane's violent unauthorized departure from the class which he leaves with a parting enculé (arsehole) which is not subtitled.

The field of discourse suggests that taboo language may be one of the properties of the discourse represented because it is the topic of conversation and because of the 
raised tempers. The tenor of discourse described in terms of the relationship between the participants might be expected to preclude taboo language use because one of the participants is a teacher but, again, the anger involved, following Jay, makes it more likely. The use of the derogatory word pétasse by the teacher provokes outrage because, as is obvious in the exchanges transcribed above, the students perceive his usage to be far stronger and more derogatory (equivalent to prostitute) than Marin does (he defines it as girls who laugh stupidly later), and because it is not part of his normal register. Marin's use of pétasse is a dramatic use of what the students perceive as taboo language in a setting where a teacher would not be expected to use nonstandard language, let alone taboo language, regardless of the different significance he and the students place upon the word. In terms of function then, this taboo word has a specific narrative function which is maintained in the subtitles. Marin's initial usage expresses the "emotion information" of anger at the girls' behaviour but subsequent utterances in the scene simply repeat the term as the topic of discussion. It is different to the Raining Stones example of Father Barry's use of fuck in that, although indeed a non-standard word, for Marin, it is not taboo, it is the students who attach taboo properties to it. Nonetheless, it still represents for the audience a marked shift out of standard language by Marin, which serves the plot and the depiction of his character. As with the Father Barry example from Raining Stones, there is no preceding taboo language use which could cue the experience of taboo language for the subtitle audience and enable omission of Marin's use of the non-standard/ taboo word pétasse in the subtitle. Its omission in the subtitles would not only undermine the impact of the utterance, it would also undercut a major plot device. Similarly, given the backgrounds of the students, prior examples of routine taboo language use and the film genre, although the use of taboo language might be employed to cue audience expectations and enable omission in different circumstances, the integral function of the word (narrative device and topic of conversation) means that would not be appropriate here. There is, however, evidence of the effect of cueing at the end of the scene in the non-subtitling of Souleymane's parting insult for which, arguably, there is enough processing time.

\section{Conclusion}

Bearing in mind that the data set in question in this article is relatively small, the following conclusions can be drawn. The macro approach to the analysis derives first from the consideration of genre as a factor in the omission of taboo vocabulary and expressions and secondly from the relationship between the register of speech produced by characters on their first appearance and the register of their speech in the analysed scenes. The case made for identifying the cueing of audience reactions by partial transfer of taboo language as a way of efficiently managing processing restrictions within an overall system of subtitles in the genre analysed here rests on hypotheses about audience expectations of discourse containing taboo language. As indicated earlier, however, it is much more likely that such a strategy will be apparent when extended sequences of taboo language feature in dialogue. The analysis of the examples reveals in some instances, in example one and in particular in example two, some partial transfer of film dialogue taboo language into subtitles which I am arguing may indicate the practice of subtitlers cueing audience reactions to the dis- 
course practice of certain characters. In Guillot (2012a, 2012b)/Fowler's (1991, 2000) terms, normal communicative competence is sufficient in audience members to recognise the triggers that are provided. The combination of the particular film genre of social realism and the concordant register properties of field and tenor, plus the register and background of the characters involved in the exchanges do, in these two examples, appear to set up perceived expectations of discourse representations which will feature taboo language. In example two, the macro context of genre plus visual information enables some cueing which helps the subtitle system deal efficiently with the difficulties involved in processing taboo language. While the combination outlined above suggests the promotion of a cueing strategy, it also performs a second function: where cueing is not employed and taboo language is transferred, the film genre, the register properties of field and tenor, plus the register and background of the characters, appear to override any perceived politeness restrictions in the transfer of taboo language from the spoken to the written mode because omission or attenuation are not employed as subtitling strategies to deal with taboo language.

The functions of taboo language tend to be contributions to characterisation or indicators of field and tenor of discourse. In terms of Jay's (2009) "emotion information" the taboo language functions in the examples, characterised as they are, by conflict situations, encompass anger and frustration, all of which are effectively conveyed in the subtitles through the retention of taboo language or through cueing. In addition, there are two examples (three and four) where taboo language use in the ST fulfils the function of a departure from expected register use which, in both cases, serves a narrative and characterisation function. In these two cases, although the taboo words are uttered within the same genre as the other examples provided, because they are departures from established standard speech practice by these characters the use of cueing based on previous use of taboo language in the TT would not be feasible. What is more, they are isolated instances of taboo language use meaning that there is no capacity for the kind of partial transfer which provides the trigger for audience experience of taboo language demonstrated in the L'Esquive and the first Raining Stones examples. The pétasse example is unsuitable for taboo language to be used to cue audience experience of taboo language for the further reason that the taboo words are the topic of conversation. They differ in this respect from the kind of non-propositional usage which Tveit (2004) identifies and which can be seen providing cues for subsequent omission in the L'Esquive extract.

The homogenisation/levelling argument that even partial omission of taboo language has a detrimental effect on the perception of character cannot be sustained on the evidence of the examples analysed. This is due to the same combination of factors described above: the properties of the genre, the overall register of the characters and the attendant expectations of discourse use these two factors are likely to generate, enable partial cueing of taboo language, both linguistically and visually without any obvious effect on the perception of character. This evidence does thus appear to provide, applied to specific contexts, a refinement of existing findings in audiovisual translation research about the homogenising/levelling effect that the omission of taboo language in subtitles produces. As demonstrated above, cueing can be achieved visually as well as linguistically. This brings the debate back to Hatim and Mason (1997: 82) who note that paralinguistic features are part of the meaning of which a subtitler has to take account. This is a crucial point. A further factor which 
has emerged, which seems to enhance the likelihood both of taboo language in the film dialogue ST and of taboo language cueing audience experience of the functions of taboo language in the TT when taboo language is omitted, is the depiction of conflict, especially physical conflict. The latter provides visual triggers for the audience that render the complete transfer of taboo language redundant. This is present in the L'Esquive example but most obvious in the Raining Stones example where the constraint of processing time clearly requires omission but linguistic and visual cueing provide an efficient way of communicating the linguistic meaning of the exchange of insults in particular.

It needs to be emphasised that these findings relate to Metropolitan FrenchBritish English, British English-Metropolitan French pairs and that other types of French and English may produce different results. Similarly, cultural asynchrony, which is not especially evident here, in terms of degrees of taboo and consequent subtitling practice is more likely to be marked between cultures which are more divergent than those looked at here and would be a productive way of taking this cross-cultural work forward. The hypothesis suggested in this article could also be further investigated by looking at the subtitling of taboo language in other film genres which depict characters for whom the field and tenor of discourse at the level of genre and at the level of character promotes the use of taboo language. For instance, does the gangster film genre reveal evidence of the cueing of taboo language in subtitles? Another genre likely to depict characters for whom the field and tenor of discourse at the level of genre and at the level of character promotes the use of taboo language is the war film genre which would probably contain a high incidence of the other factor identified here as playing a cueing role in the subtitling choices for the transfer of discourse containing taboo language, that of physical conflict. It would be interesting to see if similar practice can be observed, while using the macro factor of genre could bring insights to the study of other aspects of non-standard language use. Beyond these further questions, this analysis has, I hope, added further weight to the argument for taking a macro approach to audiovisual translation (implicit here, as I have demonstrated, in a consideration of genre) as developed by PérezGonzález (2007) and Guillot (2102a, 2012b)/Fowler (1991, 2000) in particular. Such an approach has the potential to be very fruitful for audiovisual translation research in general, especially if it encourages researchers to respond to the call from, among others, Díaz Cintas (2001), Gambier (2003; 2009) and Guillot (2010) for more detailed and sophisticated reception-based studies where the general audience expectations that I have only been able to speculate about here can be verified and explored in an empirical way.

Other questions which could usefully be addressed for the subtitling of taboo language in particular concern different functions of taboo language to those shown here, for example when it is used in non-conflict situations or situations of playful conflict as a marker of solidarity. The subtitling of taboo language in different types of subtitling where the mode of engagement is not the same as for cinema or DVD viewing merit investigation as well; fansubbing, for example, where technical restraints, norms and audience expectations differ, or computer games where audience expectations of discourse representation also differ from cinema films, in part because of a dominance of genres which include contexts of conflict and physical violence which promote taboo language. 


\section{NOTES}

1. When referring to social realism henceforth the specific context of social realism depicting low socio-economic groups is implied.

2. To explain the use of the term 'reaction' I borrow Guillot's footnote (2012b: 491): “The use of the term 'reaction' reflects the distinctions borrowed from Chesterman (2007) in Gambier (2008) to draw attention to the absence of consensus on the question of reception of AV products, i.e., reactions on the cognitive level, responses in behavioural terms, and repercussions of a cultural order."

3. The differences between scripted dialogue and naturally occurring language are well-documented but this data nonetheless provides useful categorisations of the emotional functions of taboo language use.

4. Games of Love and Chance (2006): English version of L'Esquive (2004). Directed by Abdellatif Kechiche. Lola Films and CinéCinémas, France. Distributed by New Yorker Video, New York. Subtitler information not available.

5. Raining Stones (2004): French version of Raining Stones (1993). Directed by Ken LoACH. Channel Four Films and Parallax Pictures, United Kingdom. Distributed by Diaphana Vidéo, Paris. Subtitler information not available.

6. The Class (2008): English version of Entre les murs (2008). Directed by Laurent Cantet. Haut et Court and France 2 Cinéma, France. Distributed by Artificial Eye, London. Subtitler information not available.

\section{REFERENCES}

Agost, Rosa (1997): Diversitat tipològica i traducció audiovisual. In: Maria Dolores Burdeus, Manuel Garcia Grau, and Joan Peraire, eds. La diversitat discursiva. Castelló: Universitat Jaume I, 289-305.

BELL, Allan (1984): Language style as audience design. Language in Society. 13:145-204.

Chambers, Jack, K. and Trudgill, Peter (1998): Dialectology. Cambridge: Cambridge University Press.

Chaume, Frederic (2004): Film Studies and Translation Studies: Two Disciplines at Stake in Audiovisual Translation. Meta. 49(1):12-24.

Chen, Chapman (2004): On the Hong Kong Chinese Subtitling of English Swearwords. Meta. 49(1):135-147.

Chesterman, Andrew (2007): Bridge concepts in translation sociology. In: Michaela Wolf and Alexandra FukAri, eds. Constructing a Sociology of Translation. Amsterdam/Philadelphia: John Benjamins, 171-183.

Delabastita, Dirk (1990): Translation and the Mass Media. In: Susan Bassnett and André Lefevere, eds. Translation, History and Culture. London: Pinter Publisher, 97-109.

Díaz Cintas, Jorge. (2001): Sex, (sub)titles and videotapes. In: Lourdes Lorenzo García and Ana M. Pereira Rodríguez, eds. Traducción subordinada II: el subtitulado (inglés-español/ galego). Vigo: Universidade de Vigo, 47-65.

Díaz Cintas, Jorge. and Remael, Aline (2007): Audiovisual Translation: Subtitling. Manchester: St. Jerome.

FawCett, Peter (1997): Translation and Language: Linguistic Theories Explained. Manchester: St. Jerome.

FonG, Gilbert C. F. (2009): The two worlds of subtitling: the case of vulgarisms and sexuallyoriented language. In: Kenneth K.L. Au and Gilbert C.F. Fong, eds. Dubbing and Subtitling in a World Context. Hong Kong: The Chinese University Press, 39-62.

Fowler, Roger (1991): Language in the News: Discourse and Ideology in the Press. London: Routledge.

FOWLER, Roger (2000): Orality and the theory of mode in advertisements. In: Marie-Noëlle Guillot and Marie-Madeleine Kenning, eds. Changing Landscapes in Language and Language Pedagogy. London: AFLS/CiLT, 26-39.

Franco, Eliana (2001): Inevitable Exoticism: The Translation of Culture-Specific Items in Documentaries. In: Rosa Agost and Frederic Chaume, eds. La traducción en los medios audiovisuales. Castelló: Universitat Jaume I, 177-181. 
Freddi, Maria and Pavesi, Maria (2009): Analysing Audiovisual Dialogue: Linguistic and Translational Insights. Bologna: CLUEB.

Gambier, Yves (2002): Les censures dans la traduction audiovisuelle. TTR. 15(2):203-221.

Gambier, Yves (2003): Screen transadaptation: Perception and reception. In: Yves Gambier, ed. The Translator. 9(2):171-89.

Gambier, Yves (2008): Recent developments and challenges in audiovisual translation research. In: Delia Chiaro, Christine Heiss and Chiara Bucaria, eds. Between Text and Image: Updating Research in Screen Translation. Amsterdam: John Benjamins, 11-33.

Gambier, Yves (2009): Challenges in research on audiovisual translation. In: Anthony Pym and Alexander Perekrestenko, eds. Translation Research Projects 2. Tarragona: Intercultural Studies Group, 17-26.

Goris, Olivier (1993): The Question of French Dubbing: Towards a Frame for Systematic Investigation. Target. 5(2):169-90.

Greenall, Annjo Klungervik (2011): The non-translation of swearing in subtitling: Loss of social implicature? In: Adriana Şerban, Anna Matamala and Jean-Marc Lavour, eds. Audiovisual Translation in Close-Up: Practical and Theoretical Approaches. Bern: Peter Lang, 45-60.

Guillot, Marie-Noëlle (2007): Oral et illusion d'oral: indices d'oralité dans les sous-titres de dialogues de film. Meta. 52(2):239-59.

Guillot, Marie-Noëlle (2008): Orality and film subtitling: the riches of punctuation. The Sign Language Translator and Interpreter. 2(2):127-147.

Guillot, Marie-Noëlle (2010): Film subtitles from a cross-cultural pragmatics perspective: Issues of linguistic and cultural representation. The Translator. 16(1):67-92.

Guillot, Marie-Noëlle (2012a): Film subtitles and the conundrum of linguistic and cultural representation: a methodological blind spot. In: Stefan HAUSER and Martin LugInbÜHL, eds. Contrastive Media Analysis. Amsterdam: John Benjamins, 101-122.

Guillot, Marie-Noëlle (2012b): Stylization and representation in subtitles: can less be more? Perspectives: Studies in Translatology. 20(4):479-494.

Hallam, Julia and Marshment, Margaret (2000): Realism and Popular Cinema. Manchester: Manchester University Press.

Hatim, Basil and Mason, Ian (1990): Discourse and the Translator. London/New York, Longman. Hatim, Basil and Mason, Ian (1997): Politeness in screen translation. In: Basil Hatim and Ian Mason. The Translator as Communicator. London/New York: Routledge, 78-96.

Halliday, Michael (1985): An Introduction to Functional Grammar. London: Arnold.

Hofinger, Andrea and Ventola, Eija (2004): Multimodality in operation. Languages and pictures in a museum. In: Eija Ventola, Cassily Charles and Martin Kaltenbacher, eds. Perspectives on Multimodality. Amsterdam/Philadelphia: John Benjamins, 193-210.

Hughes, Susan (1992): Expletives of lower working-class women. Language in Society. 21:291-303.

Ivarsson, Jan and Carroll, Mary (1998): Subtitling. Simrishamn, Sweden: TransEdit.

JAY, Timothy (1992): Cursing in America: a psycholinguistic study of dirty language in the courts, in the movies, in the schoolyards, and on the streets. Philadelphia: John Benjamins.

JAY, Timothy (2000): Why We Curse: A Neuro-Psycho-Social Theory of Speech. Philadelphia: John Benjamins.

JaY, Timothy (2009): The Utility and Ubiquity of Taboo Words. Perspectives on Psychological Science. 4(2):153-161.

Kozloff, Sarah (2000): Overhearing Film Dialogue. Berkley: University of California Press.

LAMBERT, José (1990): Le sous-titrage et la question des traductions. In: Reiner ArNTZ and Gisela Tноме, eds. Übersetzungswissenschaft: Ergebnisse und Perspektiven. Tübingen: Gunter Narr, 228-238.

Mailhac, Jean-Pierre (2000): Subtitling and Dubbing, for Better or Worse? The English Video Versions of Gazon maudit. In: Myriam SALAMA-CARR, ed. On Translating French Literature and Film II. Amsterdam/New York: Rodopi, 129-154.

Mason, Ian (2000): Audience Design in Translating. The Translator. 6(1):1-22. 
Mattsson, Jenny (2006): Linguistic Variation in Subtitling The subtitling of swearwords and discourse markers on public television, commercial television and DVD. In: Mary CARROLL, Heidrun Gerzymisch-Arbogast and Sandra Nauert, eds. MuTra 2006 - Audiovisual Translation Scenarios: Conference Proceedings. Visited on 26 November 2015,

Pérez-González, Luis (2007): Appraising dubbed conversation: Systemic functional insights into the construal of naturalness in translated film dialogue. The Translator. 13(1):1-38.

Pujol, Didac (2006): The Translation and Dubbing of "Fuck" into Catalan: The Case of From Dusk till Dawn. The Journal of Specialised Translation. 6:121-133.

RAmière, Nathalie (2006): Reaching a foreign audience: Cultural transfers in audiovisual Translation. The Journal of Specialised Translation. 6:152-166.

Remael, Aline (2004): A place for film dialogue analysis in subtitling courses. In: Pilar Orero, ed. Topics in Audiovisual Translation. Amsterdam/Philadelphia: John Benjamins, 103-126.

Scandura, Gabriela L. (2004): Sex, Lies and TV: Censorship and Subtitling. Meta. 49(1):126-134.

TAYlOR, Christopher J. (2006a): The Translation of Regional Variety in the Films of Ken Loach. In: Nigel Armstrong and Federico M. Federici, eds. Translating Voices, Translating Regions. Rome: Arcane, 37-52.

TAYLOR, Christopher J. (2006b): “I knew he'd say that!" A consideration of the predictability of language use in film. In: Mary Carroll, Heidrun Gerzymisch-Arbogast and Sandra Nauert, eds. MuTra 2006 - Audiovisual Translation Scenarios: Conference Proceedings. Visited on 26 November 2015, <http://www.euroconferences.info/proceedings/2006_ Proceedings/2006_Taylor_Christopher.pdf $>$.

Tveit, Jan Emil (2004): Translating for Television: A Handbook in Screen Translation. Bergen: JK Publishing.

VANDERShCHELDEN, Isabelle (2000): Le Sous-titrage des classes sociales dans La Vie est un long fleuve tranquille. In: Michel Ballard, ed. Oralité et Traduction. Artois: Artois Presses Université, 361-379. 